\title{
An overview of agriculture, nutrition and fortification, supplementation and biofortification: Golden Rice as an example for enhancing micronutrient intake
}

\author{
Adrian Dubock * (1)
}

\begin{abstract}
The worlds growing population and limited land resources require high intensity of food production. Human nutrition needs both macronutrients and micronutrients. One way of providing micronutrients in staple crops of the poor is biofortification, through plant breeding. All methods of plant breeding are acceptable and safe, and some methods can deliver micronutrients not achievable by other methods. Vitamin A deficiency is responsible for around 4500 preventable child deaths daily, and Golden Rice, biofortified with provitamin A, has proven potential as a costless intervention where rice is the staple crop. The Cartagena Protocol's concentration on a very narrow concern for environment is changing to embrace concern for sustainable development, food security and climate change. The World Bank is recommending the use of biofortified cereals, including Golden Rice as an example, as the norm rather than the exception in addressing malnutrition, noting that education, social marketing and mass media are important to optimise the effectiveness of any food-based approaches to malnutrition alleviation. Regulatory applications have been made for Golden Rice, transformation event GR2E, relating to the safety of human food and feed, which has been confirmed by one regulatory authority at the time of printing. Attitudes to gmo-crops, after two decades, appear to be changing, which is expected to benefit humankind and the environment.
\end{abstract}

Keywords: Food security, Biofortification, Vitamin A deficiency, gmo-crops, Golden Rice, Greenpeace

\section{Human population, agriculture and food production}

Around $71 \%$ of the world's surface is covered by water, which contributes only $1 \%$ of human food. Less than $20 \%$ of the land area is suitable for agriculture. So less than $6 \%$ of the world's surface must produce the food humans need [1]. The human population has more than doubled in the last 50 years from 3.5 billion (when I left school) to 7.5 billion today and will reach almost 10 billion people in the next 50 years [2].

For 12,000 years, humans have been continuously breeding crops for increased yield: mostly carbohydrates, an excellent human energy source. The trend to

\footnotetext{
*Correspondence: contact@goldenrice.org
}

Golden Rice Humanitarian Board more intensive production by fewer people has accelerated over the past 150 years with science and innovation driving the change: synthetic fertilisers, herbicides, fungicides and insecticides, plant breeding techniques, mechanisation and irrigation, as well as since the late 1990s the incorporation, through transgenesis-resulting in "gmocrops"-of genetic traits. Agriculture has the biggest negative impact on biodiversity of cultivated land. And yet intensive agriculture is the kindest for maintenance of global biodiversity by protection of wild lands from food production.

In the industrialised countries, for most of the time following WWII, there has been an increasing ubiquity, often imported, of plentiful and nutritious food at low prices, around $10 \%$ of family income. Larger farm units 
lead to economies of scale in production. Only around $2 \%$ of the population are farmers and produce the food for all. Ninety-eight percentage of the population have little understanding of agriculture or the technology involved, and as food is an emotional subject, it is easy to stimulate fear of food production systems.

In the non-industrialised countries, in contrast, food production is often under-resourced, requiring in some countries $60-70 \%$ of the population to be farmers. Very small farms are the norm. Land tenure and market access are two of many issues which exacerbate the difficulties in food production. Farming is not a high-status occupation, and there is a continuing migration of labour from the land in the expectation of a better life in cities. For those left behind, often the old, the work becomes ever more demanding, and less productive, with a tendency to increasing poverty. With inefficient production and poverty, food takes up a huge proportion (perhaps 50\%) of available family income in these countries.

In seeking more equitable access to food, while protecting the environment, all technologies need to be harnessed in the complex web of global agriculture. There is nothing incompatible about integrating conventional plant breeding, including mutagenesis, biotechnology and genetic modification, better soil husbandry and organic farming, agroecology management, pesticides and organic and inorganic fertilisers.

\section{Science and technology drive yield improvement: but human nutrition requires not only macronutrient yield but also micronutrients}

Following World War II in many countries, there were food shortages. Food rationing in the UK only ceased in July 1954 (when I was 4 years old). From the 1940s, the international nutritional focus was on macronutrient sufficiency. Human population was starting to increase rapidly. From the 1950s, I recall the images on a neighbours TV of emaciated Indians in ragged clothing standing in line for food handouts of imported grain. Nevertheless, in all regions of the world except Africa, per-capita food production increased for the four decades following the 1960s Green Revolution [3].

Per-capita food production as a share of per-capita production, 1961-1965 and various years (FAO data) [3]

\begin{tabular}{llcccc}
\hline Continent & \multicolumn{1}{l}{$\mathbf{1 9 6 1 - 1 9 6 5 1 9 7 1}$} & $\mathbf{1 9 8 1}$ & $\mathbf{1 9 9 1}$ & $\mathbf{2 0 0 1}$ \\
& $\mathbf{( 1 )}$ & $\mathbf{( 2 )}$ & $\mathbf{( 3 )}$ & $\mathbf{1 4 )}$ & $\mathbf{( 5 )}$ \\
\hline Africa & 100 & 103 & 94 & 90 & 90 \\
Asia & 100 & 104 & 114 & 134 & 173 \\
$\begin{array}{l}\text { South } \\
\quad \text { America }\end{array}$ & 100 & 100 & 115 & 118 & 144 \\
$\begin{array}{l}\text { World } \\
\text { Non }\end{array}$ & 100 & 107 & 112 & 115 & 126 \\
\hline
\end{tabular}

In the 1960 s, India imported up to 10 million tons of food grains and from about 2002-2012 exported 4-6 million tons annually. As a result of the "Green Revolution", rice production increased from 34.6 million tons in 1960 to 154 million tons in 2013-2014. Wheat production increased from 10.3 million tons in 1960 to 97 million tons in 2013-2014. During the same period, the population of India increased from 350 million to 1.3 billion. In 2013-2014, India exported 10.7 million tons of rice-more than any other country [4].

More recently, from the 1990s plant breeding technology improvements, driven significantly by knowledge of plant genetics, have allowed increases in yield $[5,6]$ incremental to the chemical- or irradiation-induced mutagenesis followed by selection used since the 1940s [7]:

Science and Innovation Drive Yield Improvements

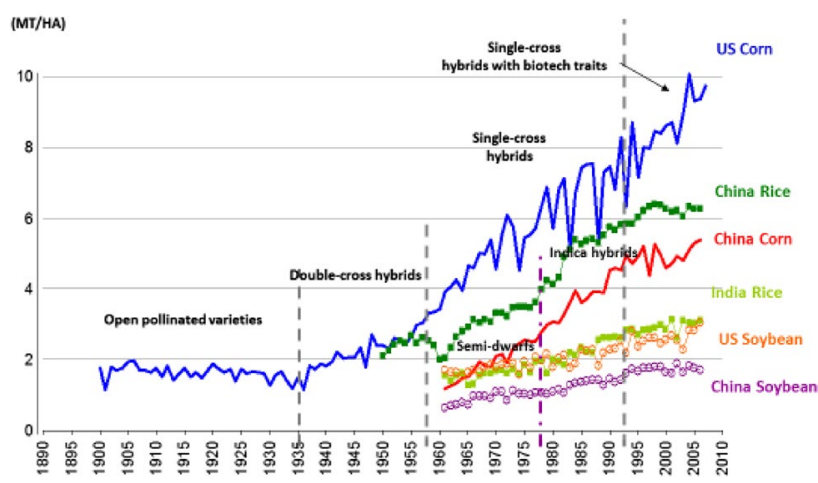

But the African situation has not caught up: "According to the Food Security Index 2016, developed western countries hold the highest levels of food security while sub-Saharan African countries are at the bottom of the rankings. Germany and France, which have opted out of cultivating GMO crops-both ranked 6/113; in contrast, Kenya ranked 83 and Mozambique 108". "...why should Africa be prohibited from growing the most technologically advanced and sustainable crops?" "[African] Farmers need and want choices, not European-imposed restrictions" [8]. Especially as Africa's population is forecast to experience by far the largest percentage change (> 100\%) of all global regions between 2015 and 2050 [9].

Poverty is often associated with very limited dietary diversity. Carbohydrate-rich grains are an important energy source. The other macronutrients, fats and proteins, are important too. However, humans also need micronutrients-minerals such as iodine, iron and zinc and vitamins such as vitamins $A, C, D, B_{1}$ and $B_{3}$ for healthy development and life. Micronutrients exist 
as either minerals, taken up from the soil and accumulated by plants, or vitamins that are synthesised either by plants or by animals. Energy-rich grains are extremely important, but without dietary diversity are not sufficient for a healthy life [5].

In industrialised countries, dietary diversity includes not only plant products, but also animal products, and populations with such a varied diet generally benefit from sufficiency of both macronutrients and micronutrients. Often poor people in developing countries have very limited access to animal products, for economic or other reasons.

Since the 1970s, first with respect to iron [10], then folate [11] and from the 1980s vitamin A deficiency [12], there has been an increasing global awareness of the preventable impact of dietary micronutrient deficiency on human health and mortality, and related reduction in the economic productivity of populations. Many meetings of the United Nations and other supranational organisations have addressed the problem of nutrition.

Notably, 129 Heads of State in Johannesburg in 2000 ratified the Millennium Development Goals. Many of these goals, to be achieved between 1990 and 2015, related to significantly better nutrition for the world's poor [13]. Despite the unity of intention, Goal 1, to eradicate extreme poverty and hunger, and Goals 4 and 5, about reducing significantly child and maternal mortality, were not achieved [14].
Calestous Juma argues powerfully that what is needed in Africa (and I would say in most developing countries) is translational application to local circumstances of already established as effective technologies, not "basic research". The mobile telephone in Africa is a good example where locally important applications have been developed, and the fixed line network did not have to be extended. Africa did not have to invent the mobile telephone to benefit [15].

The 2016 G20 Agriculture Ministers remained "deeply concerned that, despite tremendous efforts, 795 million people in the world still suffer from chronic hunger and 2 billion people from [micronutrient] malnutrition" [16]. ${ }^{1}$

\section{Vitamin A deficiency}

Human populations deficient in the minerals such as iron and zinc, and in vitamin A, suffer from a variety of serious developmental and public health issues, and these deficiencies are more widespread globally than other important micronutrient deficiencies [5]. Vitamin A deficiency, VAD, which mostly affects children less than 5 years old, and to a lesser extent their mothers, is widespread and well documented by the World Health Organisation [18].

\footnotetext{
${ }^{1}$ That these 2016 numbers are the same as a 2003 report [17] indicate either no new data, or no progress in addressing them: in either case disappointing.
} 


\section{Public health importance of vitamin A deficiency, by country}

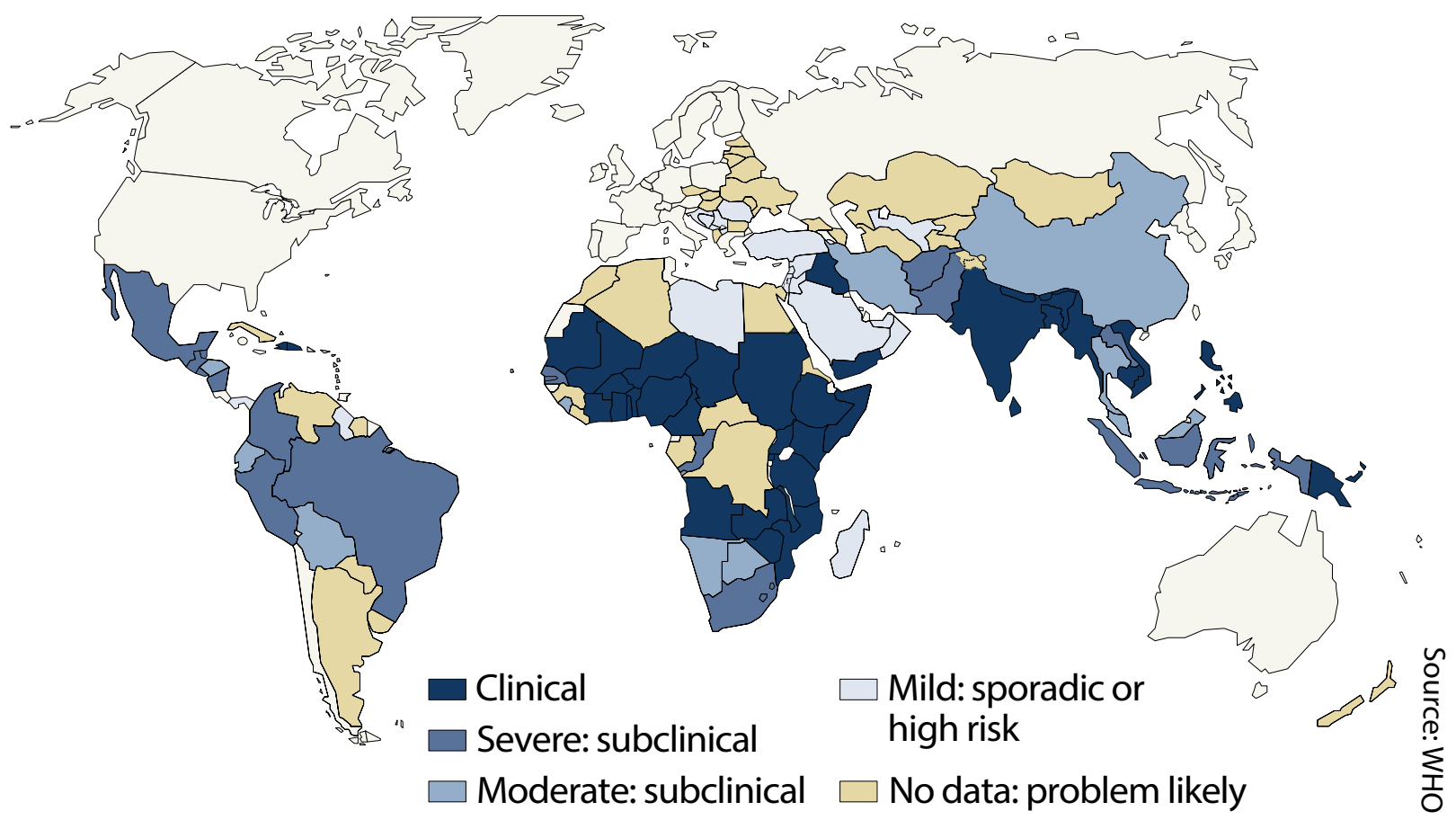

Source: WHO data. Redrawn by and produced courtesy Banson

By the 1990s, VAD was known as the major cause of childhood blindness globally, with about 500,000 cases annually, of which about two-thirds die if not treated [19]. As a result, for more than a quarter of a century, vitamin A deficiency (VAD) has been recognised by the United Nations as a significant public health problem. Key milestones included the:

- 1990 UN World Summit for Children, where 50 heads of government and senior government officials committed their governments to the virtual elimination of VAD by the year 2000 [20].

- 1992 UN International Conference on Nutrition, which concluded that

- VAD control is the most cost-effective child health/ survival strategy governments can pursue.

- All sectors of society should support the virtual elimination of VAD.

- Strategies should include promoting breastfeeding, dietary diversification, vitamin A supplementation and food fortification.

- Locally available food-based strategies are the first priority. Vitamin A capsule supplementation is only an interim measure [21].
- 2004 UNICEF and the Micronutrient Initiative Report "Vitamin and Mineral Deficiency", which concluded that "controlling vitamin and mineral deficiency is an affordable opportunity to improve the lives of two billion people and strengthen the pulse of economic development" and that "probably no other technology available today offers as large an opportunity to improve lives and accelerate development at such low cost" [22].

What was not known clearly in the 1990s was that VAD also suppresses the human immune system: VAD is "a nutritionally acquired immune deficiency syndrome" [12]. Eyesight problems and immune deficiency-related deaths are two different morbidities of vitamin A deficiency. Most who die as a result of VAD do not become blind first. Increased susceptibility to disease as a result of VAD results in the majority of the millions of preventable $<5$-year-old child deaths, mainly among children, annually $[23,24]$.

A universally available source of vitamin A could save $23-34 \%$ of all deaths of children under 5-year-old globally and reduce measles mortality by up to $50 \%$ [23, 25 , 26]. As the UN regularly measures and publishes global all-cause child mortality $[27,28]$, the importance of VAD mortality can be stated compared with other public 
health mortality causes especially important in the countries where poverty is widespread:

Global mortality from important public health diseases

\begin{tabular}{lll}
\hline Global mortality (millions) & $\mathbf{2 0 1 0}$ & $\mathbf{2 0 1 4}$ \\
\hline Vitamin A deficiency & $1.9-2.8$ & $1.4-2.1^{\mathrm{a}}$ \\
HIV/AIDS & 1.8 & $1.2^{\mathrm{b}}$ \\
Tuberculosis & 1.4 & $1.1^{\mathrm{c}}$ \\
Malaria & 0.7 & 0.6 \\
\hline
\end{tabular}

Data sources: For 2010 data [24]; for 2014 data [23, 29-32]

${ }^{\mathrm{a}}$ Mostly children < 5 years; ${ }^{\mathrm{b}}$ one in three HIV deaths is due to TB;

${ }^{c}$ mortality from TB of HIV-negative people

The meta-analyses of the effects of a source of vitamin A which have led to these estimates are based on research with vitamin A supplementation which cannot be repeated. Because the already proven benefits of vitamin A supplementation are so clear, and so dramatic, it is not ethically acceptable to have a control group (vitamin A deficient and without a source of vitamin A) in new research. There are no new data, only new analyses.

Although MDG Goal 1 was not achieved, it is clear from UN reports that there has been a continuous reduction in child mortality since the 1990s [33] and it is clear that improved living standards, for example the availability of clean water, as well as vitamin A capsule supplementation programmes, have saved the sight and the lives of millions from the effects of vitamin A deficiency. Yet vitamin A deficiency remains a very significant public health problem [23, 34], principally associated with poverty, and one that is preventable at low cost [21]. Semba has noted that the $<5$-year-old child mortality of India, maybe as a result of the low coverage of India's vitamin A supplementation programme, is equivalent to the total child mortality of the [28] sub-Saharan African countries [12].

Why is combatting VAD such a challenge? Only animals, including human beings, synthesise vitamin A. No plants contain vitamin A. The only direct sources of vitamin A itself are animal products: liver, butter, milk and eggs are excellent sources. Animals and humans synthesise vitamin A from carotenoid chemicals naturally occurring in coloured fruits, vegetables and leaves. Betacarotene ( $\beta$-carotene) is a particularly important provitamin A carotenoid found in all coloured plant foods. ${ }^{2}$ In industrialised countries, VAD is not a significant problem because a varied diet includes animal products and

\footnotetext{
${ }^{2}$ Beta-carotene, pro-vitamin A, also gives the colour to Golden Rice. At the levels found in foods, including Golden Rice, beta-carotene is classified as GRAS (Generally Considered as Safe).

www.fda.gov/food/ingredientspackaginglabeling/gras/scogs/ucm 261245 . htm.

Beta-carotene in excess of the body's requirements is excreted without conversion to vitamin A. No plants, including Golden Rice, contain vitamin A itself.
}

various sources of provitamin A carotenoids, and also there is widespread fortification of food products together with the use of vitamin supplements by newborns and pregnant and lactating women.

In the poorer sections of developing countries, food sources that are most valuable in terms of micronutrientsanimal products including milk, eggs, butter, liver and fish-are usually more expensive and "beyond the reach of poor families" [12]. Food security staple crops such as rice are cheaper and therefore make up most of the diet:

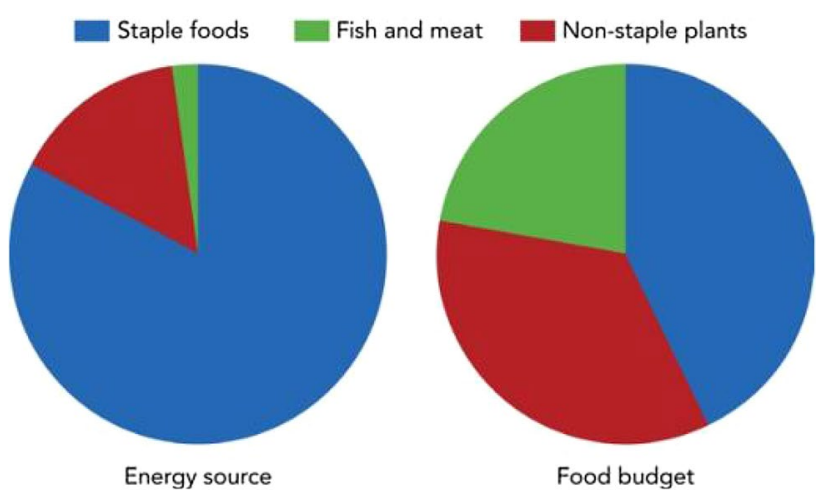

Share of energy source and food budget in rural Bangladesh. Source: www.harvestplus.org/content/food-crisis

The problem of VAD is also exacerbated by the limited bioavailability of vitamin A from fruit and vegetables [35]. It has been estimated that young children between ages 1 and 3 years would need to eat eight servings of dark green leafy vegetables per day in order to meet the recommended dietary allowance ("RDA"3) for vitamin A. These facts have resulted in the conclusion of "the virtual impossibility for most poor, young children to meet their vitamin A requirements through vegetable and fruit intake alone" [12]. Three and a half billion people daily obtain most of their calories from rice, which can, in the case of countries like Bangladesh, account for up to $80 \%$ of their calorie intake [36]. Countries where the diet lacks sufficient vitamin A suffer from relatively high infant and maternal mortality as a consequence [37].

\section{Biofortification and Golden Rice}

There are several strategies for addressing micronutrient deficiencies caused by insufficient dietary diversity. Industrial fortification (e.g. adding iodine to salt, vitamins

\footnotetext{
${ }^{3}$ The RDA for vitamin A includes sufficient to maintain 3-month liver stores of the vitamin. The RDA is derived from the upper limit of 2.5 standard deviations around the smaller estimated average requirement (EAR). Nutritionists calculate that daily consumption of $30-40 \%$ of the EAR is sufficient to prevent morbidity and mortality from VAD.
} 
A and D to margarine, fluoride to toothpaste, folic acid to flour) has been used successfully to ensure sufficiency of micronutrients to populations. Supplementation involves provision and consumption of tablets, syrup or capsules containing micronutrients and has also been employed in both industrialised and developing countries. Both fortification and supplementation, however, require some level of manufacturing and/or distribution infrastructure, and the micronutrients need to be paid for, even if they are free to the consumer. As a result, the most marginalised, and the neediest may not benefit.

A good example of supplementation is vitamin A capsules introduced to vulnerable populations starting in the early 1990s as an intervention for vitamin A deficiency $[12,23]$. At the same time, it was recognised by the 1992 UN Conference on Nutrition that "locally available foodbased strategies are the first priority and vitamin A capsule supplementation is only an interim measure" [21]. Ideally, VAD vulnerable children between 6 months and 5 years should receive a capsule every 6 months $[26,38$, 39]. Although individually costing only a few cents, provision of the capsules is costly-around US\$0.24-0.50 delivered each, so up to $\sim$ US $\$ 1.0$ annually for each child dosed twice a year [40,41], costing $\$ 1.0$ billion annually from aid agencies and mostly paid for by Canadian and US tax payers [24], and would be more if the infrastructure costs of provision in remote communities were not shared by other public health programmes, for example measles or polio vaccination programmes. As these diseases come under control vaccination, programmes will be curtailed which will effectively increase the cost of vitamin A capsule programmes.

And despite these generous donations over the last 25 years, and millions of young lives undoubtedly saved, 250 million children a year still remain vulnerable to VAD, and as a result in 2014 1-2 million $<5$-year-old preventable child deaths occurred. Even when vitamin A capsules are used, such use does not change the underlying vitamin A status of populations, which therefore remain at risk if the programmes were to be withdrawn for any reason (West, pers. comm.). Supplementation in poor populations is helpful, but is not sufficient on its own.

In 2000, two German professors, Ingo Potrykus and Peter Beyer, proved that they could modify the genome of white rice to produce beta-carotene, the precursor which the human body uses as a source to make vitamin A [42, 43]. They then donated the technology involved in the creation of Golden Rice to benefit the disadvantaged in the developing world, mindful particularly of the intractable vitamin A deficiency problems in India and other countries of Asia. Their interest in the humanitarian use of their technology was not inconsistent with commercial interest (from 2000 to $2004^{4}$ ) for industrialised countries for the same technology by the company Syngenta. A collaboration was started in 2000, whereby the inventors assigned their patents to Syngenta in return for Syngenta assistance to the inventors for humanitarian exploitation of the technology in developing countries. Improved versions of Golden Rice were created in 2004 by Syngenta scientists, and as part of its obligations under the collaboration agreement, Syngenta made selected transformation events available to the Golden Rice Humanitarian Board. The inventors licensed a network of Asian public sector rice institutes to deliver their humanitarian and altruistic objectives, and the Humanitarian Board made the new versions available to the network [24].

The terms of the inventor's licences to the government institutions ensure that the nutritional trait is only introduced into publicly owned rice varieties. Additionally, that there will be no charge for the nutritional technology, that farmers will be free to grow, locally sell, save and replant Golden Rice seed, and that the nutritional trait can only be stacked with other transgenic traits also under the control of the public sector institutions for humanitarian applications [24]. In this way, there will not be only one Golden Rice, but many Golden Rice varieties with in each case the nutritional trait carried in rice varieties adapted to the local growing conditions and preferred locally by the growers and consumers.

The first licensee of the Golden Rice inventors, in 2001, was the International Rice Research Institute, (IRRI) a not-for-profit institute established in the Philippines. All the other 15 Golden Rice licensees are rice laboratories of national governments. IRRI has been instrumental in breeding the selected nutritional trait, transformation event GR2E-responsible for otherwise white rice synthesising beta-carotene, into four mega-varieties of Oryza sativa, Indica rice. These Golden Rice varieties will be planted (following registration by national authorities) in some countries. In others, they will be used as breeding parents to introduce the trait into different locally preferred and agronomically adapted rices.

"Golden Rice" is the first purposefully created biofortified food. It is a rice that synthesises and accumulates $\beta$-carotene during seed maturation [42]. Following normal harvesting, grain polishing, storage, cooking and consumption, the human body efficiently converts the $\beta$-carotene in Golden Rice to vitamin A [44]: "In summary, the high bioconversion efficiency of Golden Rice beta-carotene to vitamin $A$ shows that this rice can be

\footnotetext{
${ }^{4}$ Zeneca was one of two companies which merged to create Syngenta in 2000. In October 2004, Syngenta filed a statement about Golden Rice with the US Securities and Exchange Commission which included "Syngenta has supported this public project from its inception and will continue to do so. The company has no commercial interest in the Golden Rice project".
} 
used as a source of vitamin A. Golden Rice may be as useful as a source of preformed vitamin A from vitamin $A$ capsules, eggs or milk to overcome VAD in rice-consuming populations" [24, 45, 46], "so that a few ounces of cooked rice can provide enough to eliminate the morbidity and mortality of Golden Rice" [47].

Calculations suggest that $40 \mathrm{~g}$ of dry Golden Rice, after normal harvest, polishing, storage and cooking, when consumed daily, will save life and sight of people who would otherwise be vitamin A deficient (see footnote 3) [24].

\section{Plant breeding and safety}

Traditionally improvements to plants have been achieved by crossing plants of the same species, observing the plants which arise from the random mixing of genes which occurs in the reproductive process, and selecting the individual plants with the most useful characteristics for the next round of cross-breeding. Over 12,000 years, the approach has gradually improved domesticated plants. Initially, it was carried out by the early farmers, and since the latter part of the 1800 s by more specialised plant breeders, who increasingly combine careful observation and record keeping with biological understanding. Contrary to other claims to the accolade, it is probably plant breeding which is "the oldest profession".

For this seed breeding approach to work, the starting population of plants has to exhibit a range of expression for any given trait (or characteristic). Since the 1940s, chemical or nuclear irradiation of growing plants, or their seeds, has been used to induce more genetic mutations than usual in the target plants, so that random combinations may create ever more useful variation in traits for the plant breeders to select from [48]. Most of the crops we are familiar with have been produced in this way. There are hundreds of crop plant varieties (including 826 rice varieties) in use today produced by this system of induced mutagenesis. The mutation process itself is random and can affect hundreds or thousands of a plant's genes and delete whole chromosomes. Plant breeders discard the plants which are not useful, and retain the ones which are. Selected plants have their biological performance confirmed by growth in open-field conditions and then are adopted as approved varieties.

This seed breeding approach cannot be used with crops which do not reproduce sexually; examples include the important food security crops plantain and cassava. In sexually reproducing crops, for example rice, the seed breeding approach can only be used effectively to improve traits for which trait variation in the plant species already exists.

Research with different crops has shown that there is a similarity in function between the genes of different plants genomes. For example, there are genes which affect root development in cereals which are common between different cereal species genomes.

When the inventors of Golden Rice started out, they considered four different scientific approaches [33]. Because there was no rice variety which exhibited yellow grains, there was no variability to exploit through the conventional plant crossing route, and it was unlikely to be effective to mutagenise rice seeds or plants. But they knew that genes inducing a yellow colour were present in some easily obtainable plant tissues. By selecting the genes giving the yellow colour to daffodil (narcissi) flowers, and introducing them to the rice genome in a way which allowed gene (and therefore colour) expression in rice seed, they were able to create the prototype Golden Rice [42, 43]. Subsequently, the Syngenta scientists took other genes known to be associated with beta-carotene synthesis in seeds, those from maize, and were able to induce synthesis of higher levels of betacarotene, both in micrograms and in percentage of total carotenoids [49]. It is this latter approach which is the basis of Golden Rice today. From either the daffodil or maize, the genes were combined with the rice genome using genetic modification techniques "transgenesis": so Golden Rice is a "gmo" (genetically modified organism). But only once, in about 2004 for today's Golden Rice: since 2004, for the past 13 years, all subsequent development of Golden Rice has been through "conventional" cross-breeding.

Much has been made of the potential differences for safety to man, animals or the environment between conventionally bred crops and gmo crops. These concerns are often conflated and inflated by association with dislike of the commercial behaviour of companies which have been most associated with the introduction of gmocrops. This is unfortunate because the effect is to reduce the ability of non-commercial entities to utilise the power of genetics, so beneficially harnessed in medicine and food processing $[33,60]$, to benefit food production.

Conversely, all independent science-based institutions globally [50-54] have found crops produced by transgenesis to be no more of concern that crops produced by any other method. There are many references, but a particularly clear one comes from the heart of the geography politically most opposed to gmo-technology, the European Commission:

"The main conclusion to be drawn from the efforts of more than 130 research projects, covering a period of more than 25 years of research and involving more than 500 independent research groups, is that biotechnology, and in particular GMOs, are not per se more risky than, for example, conventional plant breeding technologies" [51]. 


\section{Economics}

It has been calculated that conservative adoption of Golden Rice is Asian countries would add US6.4 billion to those countries GDP through increased productivity enabled by reduced vitamin A deficiency-induced sickness, and improved eyesight, and US\$17.4 billion if Golden Rice adoption encouraged adoption of other nutritional traits to rice, through increased productivity [55].

Compared with the cost of other VAD interventions, Golden Rice, fully costed with all development costs, has been calculated to be at a minimum six times cheaper per "disability adjusted life year" saved [33, 40]. This is because all the costs are "up front". The nutritional technology is in the seed, and once adoption by an area's population is assured, very little cost will be involved in project maintenance or refreshment. The seed reproduces itself, and can be replanted, mostly in the localities where it will be consumed to deliver its nutritional benefits-energy and a source of vitamin A.

Undue delay in India to making Golden Rice available has cost the Indian economy $\$ 199 \mathrm{~m}$ per year for a decade [56-58].

Combatting micronutrient deficiencies has been judged at all three separate meetings by different panels of Nobel Laureate Economists as part of the Copenhagen Consensus process, as "the best bang for a buck", that is, the most cost-effective way to solve 30 major problems faced by the world [33]. And this was established assuming the current costs of micronutrient supplementation and/or fortification, not the effectively zero cost of biofortification with a donated nutritional trait. With the donation terms of the Golden Rice inventors making Golden Rice cost no more than white rice to aid agencies, or governments or consumers, the cost-benefit of Golden Rice where rice is the staple and VAD endemic is expected to be magnificent with no need to change any cultural practices, except the adoption of Golden Rice instead of white rice by growers and consumers.

Vitamin A capsules, currently costing about US $\$ 1.00$ billion per year [24], are only recommended for children of 6 months and older [38], and very young children do not consume solid food. The capsules are not recommended for children younger than 6 months due to toxicity concerns from the vitamin A [39], yet these very young children are the most vulnerable to vitamin A deficiency: neonate deaths in 2011 accounted for 43\% (increased from $36 \%$ in 1990) of all deaths among under 5 -year-olds [27]. It is anticipated, but so far unproven, that a good source of vitamin A, such as Golden Rice, when part of the staple diet, can improve the mother's vitamin A status, benefiting her health, and simultaneously via the placenta and breast milk increase her baby's resistance to disease, and reduce neonate and $<6$-month-old child mortality, as well as benefiting 6-month- to $<5$-year-old child and maternal health.

\section{Anti-gmo-crop political activism}

The seminal Ye et al. paper [42], published on 14 January 2000, announced that the teams of Potrykus and Beyer had succeeded in their "proof of concept" research, demonstrating that the genome of white rice could be changed so that it synthesised and accumulated beta-carotene in the endosperm. It was published in the high-impact journal "Science", published in the USA, after the UK published journal "Nature" had rejected it. This was a gentle portend of political opposition to Golden Rice to come: Europe had been vociferously opposing all gmo-crops for the previous 3 years.

Only two press releases have been issued concerning the Golden Rice humanitarian project. The first was on 16 May $2000^{5}$ announcing the collaboration between Zeneca Ltd (later Syngenta) and the inventors:

"The collaboration will help the inventors of 'Golden Rice' to deliver their gift of nutritionally-enhanced rice to the developing nations of the world, bringing closer the health benefits for countries where Vitamin A deficiency is the cause of 500,000 cases of irreversible blindness each year".................Dr. Gary Toenniessen, Director for Food Security at the Rockefeller Foundation, endorsed the agreement, saying, "this collaboration will speed the process of conducting all appropriate nutritional and safety testing and obtaining regulatory approvals. The agreement should help assure that 'Golden Rice' reaches those people it can help most as quickly as possible. We look forward to following the progress of this agreement as a possible model for other public-private partnerships designed to benefit poor people in developing countries"................."Zeneca will explore commercial opportunities for sales of 'Golden Rice' into the growing market for healthy foods. At the same time, Zeneca will provide regulatory, advisory and research expertise to assist in making 'Golden Rice' available in developing countries. 'Golden Rice' has the potential to provide massive benefit countering Vitamin A deficiency-related diseases including irreversible blindness.................."The collaborators anticipate that 'Golden Rice' will not be available for local planting and consumption until 2003 at the earliest".

I was at the time working for Zeneca, and had, for the company, proposed the structure and negotiated the

\footnotetext{
5 The second, on 14 October 2004-World Food Day in the UN's International Year of Rice, announced the donation by Syngenta, consistent with its legal obligations to the inventors entered into in 2001, of selected transformation events produced by Syngenta scientists to the Golden Rice Humanitarian Board. One of these events is GR2E, the basis of Golden Rice which is expected to be registered for use.
} 
above collaboration with Professor Potrykus, and Dr (now Professor) Beyer, the inventors, and related agreements with necessary third parties $[24,37,43]$. I received an invitation by Friends of the Earth, Europe, to attend a Conference "Sustainable Agriculture in the New Millennium" in Brussels, 28-31 May 2000. The vitriolic animus of the comments made after my brief presentation "Sustainable Biotechnology: Golden Rice and Co-operation between the Public and Private Sector" felt horrible. However, the conference organisers were civil. Written before leaving it, the conclusion to the conference is prefaced: "Some of the concerns voiced from participants at the conference representing the variety of stakeholders in the debate are summarised below, firstly, the views of industry and secondly, those of consumers in the south". I wrote the industry view (see footnote 5).

From this beginning, for the last 16 years, there has been an ongoing low level but impactful publicity insurgency against the Golden Rice humanitarian project by anti-gmo activists, punctuated by a few large battles. Many anti-gmo activist organisations have been involved. The most strident and constant has been Greenpeace. The highlights:

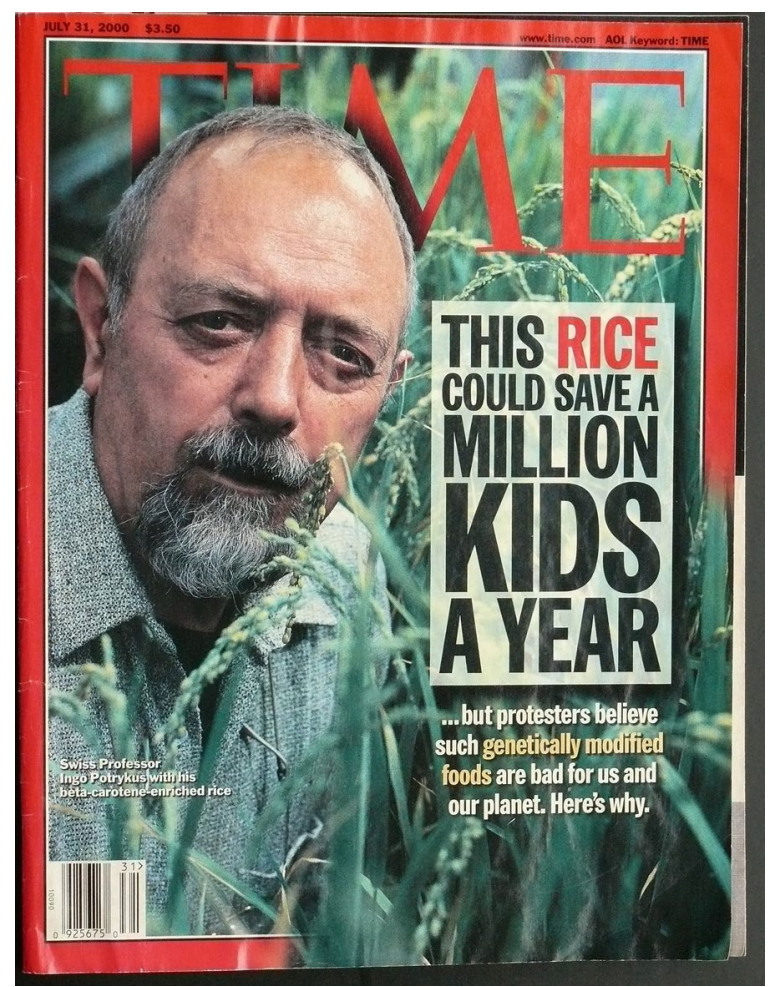

Time Magazine US edition 31 July 2000. Cover headline: "This rice could save a million kids a year...but protesters believe such genetically modified foods are bad for us and our planet. Here's why." [33].

(Time Magazine European edition. No Golden Rice story appeared.
Time Magazine, Asian edition. February 12th 2001. Cover headline: "This rice could save a million kids a year...but protesters believe such genetically modified foods are bad for us and our planet. Is the rice worth the risk?".)

\section{Greenpeace Press Release 12 February 2001.}

Genetically modified "Golden Rice" containing provitamin A will not solve the problem of malnutrition in developing countries, according to Greenpeace...... Greenpeace calculations show however, that an adult would have to eat at least 3.7 kilos of dry weight rice, i.e. around 9 kilos of cooked rice, to satisfy their daily need of vitamin A from "Golden Rice".. [59]

\section{Greenpeace Press Release, 2012.}

On 8 August 2012, Tang et al. published online the results of research initially planned in 2003 and completed in June 2008. The authors found: "In summary, the high bioconversion efficiency of GR b-carotene to vitamin A shows that this rice can be used as a source of vitamin $A$. GR may be as useful as a source of preformed vitamin A from vitamin A capsules, eggs or milk to overcome VAD in rice-consuming populations".

Greenpeace commented 3 weeks later, on 29 August 2012:

"Greenpeace alarmed at US-backed GE food trial on Chinese children"......" It is incredibly disturbing to think that an American research body used Chinese children as guinea pigs for genetically engineered food,....

The relevance of this study is questionable,....

Nor does high conversion rate solve all the technical environmental and ethical issues around Golden Rice" [60 also reported at 61].

Following this Greenpeace Press release, and despite Tufts University finding "no concerns related to the integrity of the study data, the accuracy of the research results or the safety of the research subjects" [45], Tang et al. 2012 was retracted by the American Society of Clinical Nutrition in 2015 [62]. ${ }^{6}$

The National Academy of Science and Technology ("NAST") Philippines commenting on Golden Rice Field Trial destruction, Philippines, 8 August 2013:

"The NAST deplores the disruption of the.......... field experiment by anti-GMO elements who uprooted the month-old transplanted golden rice plants ......... on 08 August 2013. NAST considers this as

\footnotetext{
6 "The recent retraction and censure of Tang et al's study on pro-vitamin A supplementation with Golden Rice in Chinese children, possibly the single best support for its humanitarian use as a functional food, has had crippling effects on further academic interest in GM functionalization (despite the distinct taint of political motivation behind Tufts University's ethical inquest) [referencing 60]. The potential benefits of Golden Rice have been suppressed for now, by a weakness to social pathogens rather than biological" [63].
} 
an act of sabotage of a lawfully and responsibly-conducted scientific experiment. Thus far, no adverse environmental effects have been reported on the nine completed field trials. The golden rice crop that was sabotaged was the third such planting in the same site since March 2012" [60, 64].

Science Editorial commenting on Golden Rice Field Trial destruction, Philippines, 8 August 2013:

\begin{abstract}
"The global scientific community has condemned the wanton destruction of these field trials, gathering thousands of supporting signatures in a matter of days. ${ }^{7}$ If ever there was a clear-cut cause for outrage, it is the concerted campaign by Greenpeace and other nongovernmental organizations, as well as by individuals, against Golden Rice............... We, and the thousands of other scientists who have signed the statement of protest, stand together in staunch opposition to the violent destruction of required tests on valuable advances such as Golden Rice that have the potential to save millions of impoverished fellow humans from needless suffering and death." [65]
\end{abstract}

The political aspects of opposition to Golden Rice as an example of gmo-crops have been written up in detail elsewhere [60]. And not only the authors of the "Science" editorial have decried Greenpeace's opposition to Golden Rice. In addition, one of the founders of Greenpeace, Patrick Moore $[66,67]$ has actively campaigned against them on this topic, as well as Stephen Tindale [68], former Executive Director of Greenpeace UK and Chairman of the Greenpeace European Unit. Other gmo-crop-opponentsturned-supporters include Mark Lynas: "What we didn't realise at the time was that the real Frankenstein's monster was not GM technology, but our reaction against it" [69].

Kumi Naidoo when appointed head of Greenpeace International, in late 2009, was reported to say: "in view of developments like Golden Rice, Greenpeace must reconsider its position with regards to GMOs. We must make sure not to miss new and important developments" [70].

I immediately wrote to him welcoming the suggestion, and offering support. I received a reply from one of his staff (only) informing me that he, the staff member, was in charge of Greenpeace's anti-gmo campaign, and if I had any further comment to make I should address him only.

Many activists initial objections to gmo-crops are that they were only for industrialised farmers, in industrialised countries, for multinational profit and with no consumer benefit; that they were dangerous for environmental and human health, and their exploitation involved

\footnotetext{
${ }^{7}$ Reference referred to in the quotation: B. Chassy et al. (2013) "Global scientific community condemns the recent destruction of field trials of Golden Rice in the Philippines"; http://chn.ge/143PyHo.
}

intellectual property rights which would eventually lead to commercial domination of food production.

When it was demonstrated that Golden Rice, a gmo crop, did not conform with this stereotype, first of all the activists tried to prove it could not be effective and then tried to vilify or destroy the research which demonstrated its potential. Finally, after demolition of all their arguments, they claimed that Golden Rice was a "Trojan Horse" being manipulated by its proponents merely as a device to create more valuable commercial opportunities for multinational companies to exploit gmo-crops, create new farmer dependencies and remove farmer choice. In all the polemics supporting the anti-gmo stance, it does not take long for anti-business emotions to emerge: seemingly this is the strongest common cause of opponents.

\section{Postscript}

The outline for the paper above was given verbally at the Biovision Conference in Alexandria, Egypt, on 14 April 2016. Subsequently, related activities have occurred which have a bearing on the title. They are presented here, followed by some discussion, and conclusions.

(a) June 2016: Sir Richard Roberts FRS and other Nobel Laureates (currently, 126 in total) supported by other people ( $>13,000$, from $\sim 100$ countries) published an open letter ${ }^{8}$ :

\section{"June 29th 2016}

To the Leaders of Greenpeace, the United Nations and Governments around the world

The United Nations Food \& Agriculture Program has noted that global production of food, feed and fibre will need approximately to double by 2050 to meet the demands of a growing global population. Organizations opposed to modern plant breeding, with Greenpeace at their lead, have repeatedly denied these facts and opposed biotechnological innovations in agriculture. They have misrepresented their risks, benefits and impacts and supported the criminal destruction of approved field trials and research projects.

We urge Greenpeace and its supporters to re-examine the experience of farmers and

\footnotetext{
${ }^{8}$ There are approximately 290 living Nobel Laureates, so 126 signatories represent $43 \%$ of them supporting Golden Rice: thank you Nobel Laureate signatories, as well as the $>13,000$ other people who have signed in support! Additional to the Nobel Laureates open letter, the website http://supportprecisionagriculture.org/ has an extensive set of easy to navigate data concerning Golden Rice and modern biotechnology, including transgenesis which Sir Richard Roberts has called "Precision Agriculture". The website is also available in six other languages.
} 
consumers worldwide with crops and foods improved through biotechnology, recognise the findings of authoritative scientific bodies and regulatory agencies, and abandon their campaign against "GMOs" in general and Golden Rice in particular.

Scientific and regulatory agencies around the world have repeatedly and consistently found crops and foods improved through biotechnology to be as safe as, if not safer than those derived from any other method of production. There has never been a single confirmed case of a negative health outcome for humans or animals from their consumption. Their environmental impacts have been shown repeatedly to be less damaging to the environment, and a boon to global biodiversity.

Greenpeace has spearheaded opposition to Golden Rice, which has the potential to reduce or eliminate much of the death and disease caused by a vitamin A deficiency (VAD), which has the greatest impact on the poorest people in Africa and Southeast Asia.

The World Health Organisation estimates that 250 million people suffer from VAD, including 40 percentage of the children under five in the developing world. Based on UNICEF statistics, a total of one to two million preventable deaths occur annually as a result of VAD, because it compromises the immune system, putting babies and children at great risk. VAD itself is the leading cause of childhood blindness globally affecting 250,000-500,000 children each year. Half die within 12 months of losing their eyesight.

WE CALL UPON GREENPEACE to cease and desist in its campaign against Golden Rice specifically, and crops and foods improved through biotechnology in general;

WE CALL UPON GOVERNMENTS OF THE WORLD to reject Greenpeace's campaign against Golden Rice specifically, and crops and foods improved through biotechnology in general; and to do everything in their power to oppose Greenpeace's actions and accelerate the access of farmers to all the tools of modern biology, especially seeds improved through biotechnology. Opposition based on emotion and dogma contradicted by data must be stopped.

How many poor people in the world must die before we consider this a "rime against humanity"?

Sincerely," [50] (b) September 2016: Research began to facilitate faster incorporation of the nutritional trait into more local rice varieties, following the anticipated registration of Golden Rice. Golden Rice registration, based on one selected transformation event, will occur on a country by country basis. Currently, the trait has been incorporated into four mega-rice varieties, which has been achieved by backcrossing over several generations. However, there are thousands of locally adapted and preferred rice varieties. The application of the most modern methods of precision agriculture potentially could shave years from the timelines required to introduce the nutritional trait into other nationally and locally important rice varieties.

(c) October 2016: The World Food Prize recognised Biofortification by awarding The World Food Prize 2016 to:

The three-person 'CIP' team-Drs Andrade, Mwanga and Low for developing and encouraging adoption of the orange-fleshed sweet potato (OFSP) to combat VAD, the single most successful example of micronutrient and vitamin biofortification.

Together with

Dr. Bouis, of HarvestPlus for pioneering a multiinstitutional approach to biofortification through a global plant breeding strategy. As a result, iron and zinc fortified beans, rice, wheat and pearl millet, and Vitamin A-enriched cassava, maize and OFSP are present in over 40 countries [71].

(d) November 2016: The regulatory data package for food and feed safety of Golden Rice was completed confirming, subject to independent review by government regulators, that human food and animal feed derived from provitamin A biofortified GR2E rice $[=$ Golden Rice] are as safe as food and feed derived from conventional rice varieties. ${ }^{9}$

\footnotetext{
${ }^{9}$ The Executive Summary of the regulatory data package can be found here http://www.foodstandards.gov.au/code/applications/Documents/A1138\%20 Executive\%20summary.pdf.

Detailed data files can be found here: https://www.dropbox.com/ sh/58nh6x76xtkds89/AADBxFjZozyz5tpZfDrlaZYLa?dl=0 and duplicated here: https://www.dropbox.com/sh/p9whsg5a3m5jkil/AABsDdiUjrRNUPpbeEm-rsyla?dl $=0$.

Food, Feed and Processing regulatory clearance in any country is only part of what is required to allow for Golden Rice to be grown, and consumed. In any country where Golden Rice is to be grown, environmental regulatory clearance is also required, and nowhere has this been applied for yet. As yet no one can say which will be the first country where Golden Rice is available to the public. It would also be premature to believe that any such availability is inevitable: it will depend on national regulators, and then essentially government policy in each country: is it recognised that Golden Rice has the potential to assist vitamin A deficiency alleviation and does each national government seek to see it adopted as a routine part of staple diets.
} 
(e) December 2016: Parties to the Cartagena Protocol [72], including Governments from 167 countries, met in Rome on 16 December 2016 and agreed that different governmental and economic sectors and not just environment ministries (emphasis added) must be involved in the implementation of the Cartagena Protocol. The Governments recognised this as a key action to achieve sustainable development, including ensuring food security and addressing climate change, as well as protecting biodiversity - the thousands of interconnected species that make up a vital web of ecosystem services upon which global food production depends.

"This is a turning point," said Maria Helena Semedo, FAO Deputy Director-General. "The agriculture sectors and biodiversity have often been regarded as separate and even conflicting concerns, yet they are inextricably connected. Agriculture is by nature a major user of biodiversity, but it also has the potential to contribute to its protection," she added, "Now that the international community has demonstrated its commitment to link both, we can really start building bridges, breaking down silos and tackling global challenges in a more concerted and coherent manner" [73].

(f) June 2017: The World Bank stated that "In the agricultural production sub-system at the farm level the three main pathways to improve diet quality are through: (1) ensuring that biofortified cereals are the norm, where they are available and agronomically competitive, rather than the exception; (emphasis added) (2) eliminating subsidies and other production/price support measures for production of unhealthy ingredients for food processing.

and (3) encouraging production (and consumption) of fruits, vegetables, and legumes".

With respect to 'biofortified cereals' those produced by ".......traditional plant breeding techniques (non-transgenic), such as the crops being developed by HarvestPlus........... [and others created by] genetic, or transgenic modification techniques such as the Golden Rice.............." are recognised [74].

This report also references an earlier-2013-World Bank report which recognises that multi-sectoral approaches are required to improve nutrition for women and children, noting that for food-based interventions education, social marketing and mass media are important: "simply increasing household income or raising agricultural productivity is insufficient to improve undernutrition" [75].

The 2013 report recognises that too little attention is being paid to improving and measuring improvements to nutrition, and that "one reason for the slow gains in the MDG's" (Millennium Development Goals [14]) "is the lack of investment in nutrition, the virtually "forgotten MDG"'.

One of several recommendations is "Enhancing capacity of national agricultural research institutions to promote the breeding for and dissemination of developed biofortified crop varieties..............." as a way to "Increase year-round access to and availability of high nutrient content food". Golden Rice is specifically mentioned as one example of such crops. "Typically, the most profitable, highest yielding varieties are targeted to add micronutrient dense traits so that there are no trade-offs between yield and nutritional content. Field-testing and dissemination of many of these biofortified varieties could be included under Bank-supported AES [Agriculture and Environmental Services] projects" [75].

(g) August 2017: Food Standards Australia and New Zealand (FSANZ) issue their draft "Safety Assessment Report-Application A1138 Food derived from provitamin A Rice Line GR2E” and invited public comment. ${ }^{10}$ FSANZ have concluded that "No potential public health and safety concerns have been identified. Based on the data provided in the present Application, and other available information, food derived from line GR2E is considered to be as safe for human consumption as food derived from conventional rice cultivars."11

\footnotetext{
${ }^{10}$ FSANZ 3 August 2017 Call for submissions-Application A1138 Food derived from Provitamin A Rice Line GR2E http://www.foodstandards.gov. au/code/applications/Documents/A1138\%20CfS.pdf.

${ }^{11}$ Executive summary

Food Standards Australia New Zealand (FSANZ) received an Application from the International Rice Research Institute on 16 November 2016. The applicant requested a variation to Schedule 26 in the Australia New Zealand Food Standards Code (the Code) to include food from a new genetically modified (GM) rice (O. sativa) line, GR2E. This rice line has been genetically modified to produce beta ( $\beta$ )-carotene (the predominant form of provitamin A) and other minor provitamin A carotenoids in the endosperm of the rice grain.

GR2E is a new food crop designed to mitigate vitamin A deficiency in developing countries. GR2E is not intended to be used in the Australian or New Zealand food supplies. Approving this crop will prevent trade disruption should GR2E be inadvertently present in imported shipments of milled rice. The primary objective of FSANZ in developing or varying a food regulatory measure, as stated in section 18 of the Food Standards Australia New Zealand Act 1991 (FSANZ Act), is the protection of public health and safety. Accordingly, the safety assessment is a central part of considering an application.

The Safety Assessment of GM rice line GR2E is provided in Supporting Document 1 and the Nutrition Risk Assessment is provided in Supporting Document 2 . No potential public health and safety concerns have been identified. Based on the data provided in the present Application, and other available information, food derived from line GR2E is considered to be as safe for human consumption as food derived from conventional rice cultivars (emphasis added).

FSANZ has prepared a draft variation to Schedule 26 that includes a reference to food derived from provitamin A rice line GR2E.
} 


\section{Discussion}

In her excellent 2015 paper "Food in a future of 10 billion" [47], Nina Fedoroff writes: "However, it is the case of Golden Rice, genetically modified to produce the vitamin A precursor $\beta$-carotene, that provides the paradigmatic example of an opportunity foregone to use GM technology to address a major global malnutrition issue. ........ Golden Rice remains mired in controversy and has been tied up in the regulatory process for more than a decade. Millions suffer and die while Golden Rice remains in test plots".

In Prof Fedoroff's quotation, the term "regulatory process" could usefully be explained. This is not the process following submission of a regulatory data package to nationally appointed regulators. At the time of her paper, in 2015 no regulatory submission for Golden Rice had been made in which Golden Rice could have been "tied up".

The influence of "the regulations" on gmo-crops such as Golden Rice is more subtle and has certainly been responsible for undue delay in determining if Golden Rice, as expected, can provide an additional, as well as practical, sustainable, very cheap and effective intervention for vitamin A deficiency.

For the first time in 2016 the World Food Prize recognised and encouraged the concept of biofortification of staple crops with micronutrients for public health benefits.

Consideration of the contrast between the progress of the 2016 World Food Prize Laureates-Harvest Plus's biofortification programme and the promotion of orange sweet potato as a VAD intervention-and the Golden Rice projects progress provides insight into how "Golden Rice ...has been tied up in the regulatory process for more than a decade".

The Director of "Harvest Plus", and one of the World Food Prize Laureates is Dr Bouis. Before Harvest Plus started its activities in 2003, Dr "Howdy" Bouis had already joined the Golden Rice Humanitarian Board. The current version of Golden Rice was created in 2004. In the same year, rice was providing the global population with 2,000,000 million calories per day. Sweet potato was providing 36,478 million calories, less than $2 \%$ as many:

\begin{tabular}{|c|c|c|c|c|c|c|}
\hline & verage To & Consumpti & on (Million C & ories Per D & y) from 200 & \\
\hline Crop & Africa & $\begin{array}{c}\text { Latin } \\
\text { America }\end{array}$ & South Asia & $\begin{array}{c}\text { Central } \\
\text { Asia }\end{array}$ & $\begin{array}{c}\text { Southeast } \\
\text { Asia }\end{array}$ & TOTAL \\
\hline Rice & 125,124 & 75,238 & $1,130,648$ & 14,880 & 660,979 & $2,006,869$ \\
\hline Wheat & 107,419 & 154,173 & 987,887 & 227,197 & 71,196 & $1,547,872$ \\
\hline Maize & 256,286 & 190,759 & 67,481 & 3,100 & 63,906 & 581,532 \\
\hline Cassava & 174,719 & 24,214 & 16,263 & 0 & 44,074 & 259,271 \\
\hline Groundnut & 49,335 & 5,291 & 6,595 & 271 & 166,372 & 227,864 \\
\hline Millet & 82,889 & 0 & 81,977 & 1,799 & 1,221 & 167,885 \\
\hline Sorghum & 104,694 & 1,019 & 59,129 & 0 & 0 & 164,842 \\
\hline Potato & 13,464 & 18,608 & 46,465 & 40,903 & 3,324 & 122,764 \\
\hline Beans, dry & 39,258 & 42,325 & 26,384 & 0 & $8,278.88$ & 116,246 \\
\hline Barley & 14,771 & 20,659 & 7,037 & 53,399 & 4,326 & 100,192 \\
\hline Plantain & 36,424 & 29,303 & 19 & 0 & 26,364 & 92,109 \\
\hline Banana & 6,751 & 27,478 & 11,345 & 902 & 11,336 & 57,811 \\
\hline Yam & 42,787 & 99 & 0 & 0 & 80 & 42,966 \\
\hline Sweetpotato & 23,789 & 2,155 & 3,008 & 0 & 7,526 & 36,478 \\
\hline Lentils & 603 & 807 & 11,589 & 0 & 0 & 12,999 \\
\hline
\end{tabular}

Table: courtesy Harvest Plus. 
How can it be that Harvest Plus, which started operations in 2003, and the promoters of orange sweet potato as a VAD intervention have been successful, and Golden Rice, initially created in 1999 , and with huge potential, has not yet even been grown by farmers by 2017 ?

The answer, simply, is that Golden Rice is a gmo-crop, and (until very recently) Harvest Plus crops are not and the orange sweet potato is not. ${ }^{12}$ Why has this difference had any influence on the Golden Rice project's progress?

The June 1992 Earth Summit in Rio de Janeiro, Brazil, agreed 27 Principles, initially listed in Annex One [77], which became The UN Convention on Biodiversity (“CBD” [78]. Some key Principles, quoted verbatim, are:

\section{Principle 1:}

Human beings are at the centre of concerns for sustainable development.

They are entitled to a healthy and productive life in harmony with nature.

Principle 4:

In order to achieve sustainable development, environmental protection shall constitute an integral part of the development process and cannot be considered in isolation from it.

Principle 5:

All States and all people shall cooperate in the essential task of eradicating poverty as an indispensable requirement for sustainable development, in order to decrease the disparities in standards of living and better meet the needs of the majority of the people of the world.

Only after 14 more important Principles comes Principle 15 of the CBD:

In order to protect the environment, the precautionary approach shall be widely applied by States according to their capabilities. Where there are threats of serious or irreversible damage, lack of full scientific certainty shall not be used as a reason for postponing cost-effective measures to prevent environmental degradation.

\footnotetext{
12 The use of Agrobacterium is the most common method of introducing genes between species of crops, producing transgenic-gmo-plants, including Golden Rice [42, 49]. Paradoxically, "among 291 tested accessions of cultivated sweet potato all contain transfer DNA sequences suggest that an Agrobacterium infection occurred in evolutionary times. One of the T-DNAs is apparently present in all cultivated sweet potato clones, but not in the crop's closely related wild relatives, suggesting the T-DNA provided a trait or traits that were selected for during domestication. This finding draws attention to the importance of plant-microbe interactions, and given that this crop has been eaten for millennia, it may change the paradigm governing the 'unnatural' status of transgenic crops" [76].
}

This "precautionary principle" "has long been a major impediment to good sense in public policy. It is either so obvious as to be otiose ("if there is cause for concern, be careful"), or so vague as to be meaningless. But in its most common application-'where an activity raises threats of harm to the environment or human health, precautionary measures should be taken even if some cause and effect relationships are not fully established scientifically'.......... it has been an invaluable tool for those who want to stop any new scientific development that they dislike" [79].

Greenpeace have been long-standing opponents of gmo-crops. They were involved in June 1992 in Rio at the United Nations Conference on Environment and Development, the first UN Summit meeting to include nongovernmental representatives, and subsequently boasted that "we won almost all the points we were pushing for" [80] in the writing of the Cartagena Protocol, effectively an annex to the CBD, which came into force in 2003.

Principle 15 of the Rio Declaration, from which the CBD was created, became Objective 1 of the Cartagena Protocol (again quoted verbatim):

In accordance with the precautionary approach contained in Principle 15 of the Rio Declaration on Environment and Development, the objective of this Protocol is to contribute to ensuring an adequate level of protection in the field of the safe transfer, handling and use of living modified organisms resulting from modern biotechnology that may have adverse effects on the conservation and sustainable use of biological diversity, taking also into account risks to human health, and specifically focusing on transboundary movements.

The Cartagena Protocol, which is really a subservient agreement to the CBD, has come to dominate all the first 15 principles of the CBD. The Cartagena Protocol, with currently 167 country signatories, provides the basis of national regulatory systems for gmo-crops worldwide. The Cartagena Protocol has been promoted to elevate concerns for the environment above all other concerns, contrary to the specific language of Principle 4 of CBD, and insists first of all on generation of molecular data of gmo-crops.

A plant breeder can much more quickly, and cheaply, on the basis of plant phenotype observed in open-field conditions, decide if a plant has useful characteristics or not. But in the system which Greenpeace takes pride in, traditional plant breeders work in the field is delayed for several years.

Peter Raven, a renowned plant scientist and former head of the Missouri Botanical Garden, has remarked that the Cartagena Protocol has been "hijacked" in a sense to further the "green" political agenda of attacking 
gmos $^{13}$ and modern biotechnology [81] instead of actually protecting diversity:

"Having been involved personally in the formation of the Convention on Biological Diversity in the 1980s, I am truly saddened by the fact that it has become so preoccupied with GE crops. ......... there is no valid scientific basis to assume that "biosafety" principles concerning GE organisms would have any effect whatever on the survival of biodiversity, which is so threatened throughout the world" [82].

Recently, Prof Fedoroff has suggested [83] that President Trump's administration has the opportunity to base biotech regulations on science, not fears. If this were to happen, it would be a great example for the world. But would the world follow? Unfortunately, the world did not follow the US's position in not ratifying the Cartagena Protocol which is an existential threat to global food security, and therefore global security.

Many activist organisations have cynically ignored scientific evidence about gmo crops for fundraising purposes by suggesting that gmo-crops are a unique class of agricultural product, despite longstanding scientific agreement that they are not [51-54]. Even large organisations, public and private, have actively avoided humanitarian gmo-crop-controversy-entanglement. Individual scientists have been distracted from their work [37].

Many activist organisations have also promulgated the view that gmo-crops are dangerous to human and environmental health, are solely for use in industrialised countries for "evil" multinational company profit and provide no consumer benefit. Such a narrative is false, as Golden Rice demonstrates clearly. Nevertheless, it has provided the political environment for the organic food lobby to make similar claims for commercial gain [84], despite: "when it was established in 1990, [US] Secretary of Agriculture Dan Glickman emphasized the fundamental meaninglessness of the organic designation: "Let me be clear about one thing, the organic label is a marketing tool. It is not a statement about food safety. Nor is 'organic' a value judgment about nutrition or quality" [85].

Paradoxically the activists' success in disseminating their ideas has induced the creation of that which they oppose. Only multinational companies can afford the costs and complexities, and condemnation, associated with gmo-crops. The result of Greenpeace's influence has been to reinforce commercial oligopoly for major industrial gmo-crops. The public sector and small companies can only compete with significant fortitude, perseverance

\footnotetext{
${ }_{13}$ (Genetically modified organism=) Gmo-crops are also known as Genetically Engineered "GE" crops, or "GE" organisms.
}

and unusual financial backing from commercial or philanthropic sources. University science rewards the novelty which leads to publication in scientific journals. Neither the journals, nor the universities, reward product development perseverance. Only the most dedicated academic scientist can risk a career by deviating attention from research to advocacy for an idea, and, despite scientific proof, with such little progress towards product development during such a long time, against such entrenched opposition.

One of the reasons Harvest Plus has been so successful, correctly acknowledged in the World Food Prize 2016 recognition, is that they adopted a "no-gmo-crop" strategy from 2003 purposefully to avoid the otherwise associated and expected "hurdles and criticism" [86], and so successfully raised extensive operational funding. However, Harvest Plus have also, recently, noted that conventional seed breeding techniques cannot always achieve success with increasing iron and zinc. They have acknowledged that only with precision agriculture, using transgenesis to create gmo-crops, have they achieved success with these traits in rice [87].

Increases of not only iron and zinc [88], but also folate $[89,90]$ and pro-vitamin A in staple crops of the poor $[42,49,91]$ are all extremely important for human health. All of them have been achieved using gmo-technology, where conventional breeding was not possible.

Similarly, the other World Food Prize 2016 Laureates success reflects their work with orange-fleshed sweet potato. Low et al's 2007 research with orange sweet potato showed that consumption of the crop increased vitamin $\mathrm{A}$ intake and serum retinol concentrations in young children in rural Mozambique [92]. In common with Tang et al's 1999 research demonstrating green and yellow vegetables can maintain body stores of vitamin A in Chinese children [93], the teams of both Low and Tang involved research with children in developing countries, and conventionally bred crops.

Unlike the gmo-crop hysteria induced by Greenpeace about Tang et al's 2012 research, also involving children in a developing country context, and Golden Rice [24, 60-62] there was no adverse comment when gmo-crops were not involved. Given the trenchant gmo-crop opposition of Greenpeace and others, underpinned by the Cartagena Protocol's over-precaution, it is unlikely the orange sweet potato research has been able to progress to the adoption and benefit they have demonstrated, and which has been recognised by the World Food Prize 2016, had the crop been bred using gmo-techniques (but note footnote 12).

Professor Fedoroff is correct to note that the delays in progressing Golden Rice to fulfilment of its humanitarian objectives since 1999 are regrettable. 
Nevertheless, along the way Golden Rice has contributed positively to the gmo-debate and potentially to future public health interventions from the public sector with gmo-traits.

It has already been mentioned that if Golden Rice encouraged adoption of other nutritional traits in rice, Asian countries GDP would be increased by US $\$ 17.4$ billion through increased productivity [55]. Currently, Golden Rice is the most advanced biofortified rice towards a product, and other gm traits are following: zinc, iron and (hopefully) folate [88-90]. Dr Gary Toenniessen, then Director for Food Security at the Rockefeller Foundation, was somewhat prophetic when in the 16 May 2000 announcement of the collaboration between the inventors and Zeneca, he said: "We look forward to following the progress of this agreement as a possible model for other public-private partnerships designed to benefit poor people in developing countries"................ It is notable that the traits increasing folate, iron and zinc reported above, and elsewhere [5], each created after Golden Rice's provitamin A technology, have all been introduced into rice, have only been possible using gmotechnology, have all been developed in the public sector, and (as far as I know) are all available free of charge for micronutrient deficiency interventions for populations which would benefit from them. Perhaps all have been "encouraged" by Golden Rice's example.

Transgenesis has also be used, with various levels of success so far, to introduce provitamin A traits into other important food security crops where (previously considered as) conventional plant breeding techniques could not be effective: cassava, sorghum and plantain (also called cooking banana) [5, 91], all after Golden Rice's technology was published [42, 49]. Professor Beyer's molecular pathway engineering expertise was sought by all these projects at one time or another. Again, all are principally public sector projects.

In April 2016, immediately before the Biovision conference in Alexandria, Egypt, where the first part of this paper was presented orally, the UN's World Health Organisation and Food and Agriculture Organisation together convened a technical consultation in New York: "Staple Crops biofortified with vitamins and minerals: considerations for public health strategies". A new policy seems to be in development (but has not yet appeared). The last slide in my Alexandria presentation stated: "With respect to modern plant breeding, it's time for the UN's responsibility for Global Health to outrank the UN's outdated and hugely overcautious responsibility for The Environment".
The Golden Rice Humanitarian Board has provided costless access to Golden Rice images (and written information) to textbook publishers from all continents where, almost without fail, the "Golden Rice case" is part of the secondary school or university biology, nutrition and/or ethics curriculum.

It was immediately after Sir Richard Roberts heard me speak at a South Korean Government conference in early 2012, that we discussed his ideas of getting Nobel Laureates involved in, as he said I had done, "pointing out the idiocy of many countries current policies" with respect to gmo-crops, and therefore Golden Rice. His, initiative has led to the 2016 Open letter signed by 126 Nobel Laureates, and 13,000 other people, in support of Golden Rice and gmo-crops quoted above (see footnote 8).

With respect to new research to facilitate faster incorporation of the nutritional trait into more local rice varieties, it is clear that scientists understand that science proceeds in forward leaps and sometimes backward steps, and remain keen to assist progress to Golden Rice's humanitarian objectives, and also that philanthropists are willing to support their complementary research too.

I have long been a critic (including in the text above) of the insidious negative influence exerted and enabled by the Cartagena Protocol where often spurious "concerns for the environment" have prevented the progression of other important concerns, in the case of Golden Rice for health and welfare. In 2014 I wrote: "What can be achieved.... to attempt to mitigate the risks which the Cartagena Protocol represents? Firstly, nations should not appoint ministers responsible only for 'The Environment'. Countries could usefully follow the example of the UK where the relevant Government department is called "The Department for Environment, Food and Rural Affairs". This encourages a holistic perspective balancing relevant factors: "The environment' does not exist in a vacuum" [60].

In December 2016, as mentioned above, the Parties to the Cartagena Protocol, including representatives of 167 countries and the UN's Food and Agriculture Organisation, agreed with my sentiment [73].

Maybe someone is listening.

\section{Conclusion}

The public sector holds the responsibility for public health delivery through biofortification of food security crops. For micronutrient biofortification especially, plant breeders need rapidly to catch up with the 12,000-year head-start of seed breeding for yield. Precision agriculture-including gmo-crops-now provides the tools to 
assist: for macronutrients yield, to adapt yields to climate change and other difficult growing conditions, as well as micronutrients. Most farmers using gmo-crops in 2014clearly of their free will-did so on small farms in developing countries [94]. ${ }^{14}$

Slowly, the Golden Rice project is nearing the end of its beginning. Is it too much to think that gradually the whole world is starting to accept gmo-crops are useful as well as accepting the altruistic purpose of the Golden Rice inventors, their Humanitarian Board and their network of national public sector collaborators, and the need for additional interventions for vitamin A deficiency?

Following submission of regulatory data packages to national authorities, it can be anticipated that Golden Rice will be cleared as safe to humans, animals and the environment and made available to countries and populations which want to incorporate it into their culture of rice cultivation and consumption.

Over time, independent research will be undertaken to measure the effect of Golden Rice's regular consumption on vitamin A status of individuals and populations. And in the longer term, on the effect of Golden Rice's regular consumption on the morbidity and mortality of populations which adopt it as a routine part of the staple diet.

Subsequently, if donors are not too fatigued to pay for the development, other micronutrient traits will be combined with the provitamin A beta-carotene in multi-vitamin and multi-mineral rice. Proof of concept has already been achieved for some, a long time ago for folate, and more recently for iron and zinc.

The first challenge for the Golden Rice project, however, is to enable managed adoption by rice-consuming societies where VAD is endemic. This will require effort, as described in the next paper. For the Golden Rice in the mega-rice varieties (IR64, IR36, BR29 and PSB Rc82) carrying the GR2E transformation event, it is time for the scientists and rice breeders to "pass the baton" to rice seed multipliers, to extension workers, to public health educators, to those responsible for children and women, for school meals services, to health and welfare professionals. Hopefully, philanthropy will not be so bored and exhausted by the past 17 years that they may assist in catalysing this Golden Rice adoption work.

However, chemical reactions often occur without catalysts though, albeit at a slower rate, if the elements are reactive enough. Individuals in developing countries, following registration of Golden Rice, can manage its adoption as a routine part of agriculture and consumption,

\footnotetext{
14 "In 2014, approximately 18 million farmers, the same as 2013, grew biotech crops-remarkably, about $90 \%$, or 16.5 million, were risk-averse small, poor farmers in developing countries................For the third consecutive year in 2014, developing countries planted more biotech crops than industrial countries" [94].
}

themselves, without western philanthropic or aid or NGO assistance. To do so, they must take responsibility. And get organised to assist their communities to combat the preventable blindness and death which characterises vitamin A deficiency. The result will be truly dignified and sustainable. And a major contribution to alleviation of the effects of poverty, while other methods continue to be targetted at povety alleviation itself.

The delay to Golden Rice's development has been principally due to suspicion and political interference continuously experienced since first strongly expressed in 2000 . The project should have been where it is today, with the major part of a regulatory package finished, in around 2006, 11 years ago.

Fortunately, there are fewer $<5$-year-old child deaths annually now than then: 26,000 per day in $2006 ; 16,000$ per day in both 2014 and 2015.

But the $2015<5$-year-old death toll probably still equates to around $4500 \mathrm{VAD}$ related and preventable child deaths daily, and many of them in countries where rice is the staple, usually grown close to where it is consumed.

It is not too late for opponents to take note of the Nobel Laureate's plea to stop vilifying Golden Rice, and other gmo-crops, with benefit to the environment, and humankind. They could usefully assist Golden Rice's adoption.

\section{Acknowledgements}

The Golden Rice project is a result of the vision of two German academics, who created, as "inventors", the technology and donated it to the worlds disadvantaged, together with a set of governance structures I, acting for the UK company Zeneca, put in place with them in 2001 to assist resource-poor people, especially women and children, in developing countries where rice is the staple crop, and where vitamin A deficiency is endemic.

No individual, nor organisation, involved with Golden Rice's development has any financial interest in its successful adoption. The project is humanitarian, the motives altruistic.

The International Rice Research Institute (IRRI) was the inventors first Golden Rice licensee, of 16 otherwise national rice institutes. Several companies provided costless, yet hugely valuable support, especially at the outset of the project in 2001: these included Bayer, Japan Tobacco, Mogen, Monsanto, Novartis, Syngenta, Zeneca and a company which wished to remain undisclosed. This support included establishing Golden Rice as a Humanitarian Board owned trade mark in many countries, designed to minimise "passing off" by imitators which do not contain provitamin A, and goldenrice.org as a website domain, for the same reason.

Golden Rice is not a project of the private sector, nor is it a project of the CGIAR, although both have played important parts, together with national institutes and their scientists, paid for by national budgets, in Bangladesh, China, India, Indonesia, Philippines and Vietnam. The philanthropic sector has played an essential role: the Rockefeller Foundation, the EU, the Syngenta Foundation \& USAID, but especially the Bill \& Melinda Gates Foundation, whose patience since it became involved in 2010 has been magnificent.

Apart from its many vociferous detractors, the project and its objectives have the support of very many scientists - only some of whom are referenced in this paper-and non-scientists alike globally, including the voluntary unpaid Golden Rice Humanitarian Board (Prof Ingo Potrykus, Prof Peter Beyer; Dr Gurdev Khush; Dr Gary Toenniessen; Dr Adrian Dubock; Dr Howarth Bouis; Dr Robert Bertram; Prof Matin Qaim; Prof Robert Russell; Dr Sunkeswari R Rao; and Prof Jean Pierre Jeannet, and two confidential members). The voluntary, unpaid website manager Dr Jorge Mayer, located in Australia, as well as the 
hosting of the www.goldenrice.org website on servers of the Albert-LudwigsUniversität Freiburg, Germany, are both gratefully acknowledged. For the past few years the focussed application, expertise and diligence of Dr Donald Mackenzie at IRRI has been highly appreciated. Sir Richard Roberts support in organising the support of many fellow Nobel Laureate's for Golden Rice, as well as of course the support of each individual of the other 125 Nobel Laureate's, is hugely appreciated.

The Golden Rice project, is, however, entirely the result of Ingo Potrykus and Peter Beyer's intellect and vision and the gift of their technology to help the world.

Failure has few parents; success has many. Whatever the outcome for Golden Rice in achieving its objectives of providing a free of charge nutritional enhancement to rice as an additional intervention for vitamin A deficiency: its parentage is clear.

\section{Competing interests}

The author declares that he has no competing interests.

\section{Publisher's Note}

Springer Nature remains neutral with regard to jurisdictional claims in published maps and institutional affiliations.

Received: 11 May 2017 Accepted: 7 September 2017

Published online: 06 October 2017

\section{References}

1. Glover A, European Commission. Agricultural biotechnology in Europe and Africa. 2014. http://www.nasaconline.org/dmdocuments/agric-biotech-conf/Agricultural\%20biotechnology\%20in\%20Europe\%20and\%20 Africa-Anne\%20Glover.pdf (primary source not found).

2. Anonymous. UN world population 1800 with projections to 2100 . undated. http://www.futuretimeline.net/subject/society-demographics. htm.

3. Southgate D, Graham D. Growing green: the challenge of sustainable agricultural development in sub-Saharan Africa. 2006. http://agris.fao. org/agris-search/search.do?recordID=GB2013201055.

4. Khush GS. IRRI and the green revolution in India April 2015. 2015. http:// irri.org/rice-today/india/revisiting-50-years-of-indian-rice-research/ irri-and-the-green-revolution-in-india?tmpl=component\&print $=1 \& p$ age $=$.

5. Dubock AC. Nutritional enhancement by biofortification of staple crops, chapter 12. In: Bennett DJ, Jennings RC, editors. Successful agricultural innovation in emerging economies: new genetic technologies for global food production. Cambridge: Cambridge University Press; 2013. p. 119-220.

6. Brookes G, Barfoot P. GM crops: global socio-economic and environmental impacts 1996-2014. 2016. www.pgeconomics.co.uk/pdf/2016globali mpactstudymay2016.pdf.

7. FAO/IAEA. Welcome to the Joint FAO/IAEA mutant variety database. https://mvd.iaea.org/.

8. Karembu M. How European-based NGOs block crop biotechnology adoption in Africa. 2017. https://www.geneticliteracyproject.org/2017/02/23/ european-based-ngos-block-crop-biotechnology-adoption-africa/.

9. Khokhar T, Ashiwase H. The future of the world's population in 4 charts. 2015. http://blogs.worldbank.org/opendata/ future-world-s-population-4-charts.

10. Baker et al. Iron fortification of infant formulas. Pediatrics 1999; 194(1). http://pediatrics.aappublications.org/content/104/1/119.

11. Crider K, Bailey L, Berry R. Folic acid food fortification -its history, effect, concerns, and future directions. Nutrients. 2011;3(3):370-84.

12. Semba R. The vitamin A story: lifting the shadow of death. World Rev Nutr Diet. 2012;104:207.

13. UN. Millennium development goals. 1990-2015. undated. http://www. unfoundation.org/what-we-do/issues/mdgs.html?referrer=https://. Accessed 25 Sept 2017
14. United Nations. The millennium development goals report 2015. 2015. http://www.un.org/millenniumgoals/2015_MDG_Report/pdf/MDG\%20 2015\%20rev\%20(July\%201).pdf.

15. Juma C. Technology will drive scientific progress in Africa not the other way round. Quartz Africa. 2016. https://qz.com/africa/.

16. G20 Ministers. G20 agriculture ministers meeting Communiqué. 2016. http://www.g20.utoronto.ca/2016/160603-agriculture.html.

17. Kennedy G, Nantel G, Shetty P. The scourge of'hidden hunger': global dimensions of micronutrient deficiencies. Food Nutr Agric. 2003;32:8-16. http://www.fao.org/docrep/005/Y8346M/y8346m02.htm.

18. WHO. Global prevalence of vitamin A deficiency in populations at risk 1995-2005. WHO global database on vitamin A deficiency. 2009. http:// apps.who.int/iris/bitstream/10665/44110/1/9789241598019_eng.pdf.

19. Whitcher J, Srinivasan M, Upadhyay M. Corneal blindness: a global perspective. Bull World Health Organ. 2001;79(3):214-21. http://www.who. int/bulletin/archives/79(3)214.pdf.

20. UNICEF. World declaration on the survival, protection and development of children. 1990. http://www.unicef.org/wsc/declare.htm.

21. FAO of UN. The international conference on nutrition. 1992. http://www. fao.org/docrep/v7700t/v7700t02.htm.

22. UNICEF and The Micronutrient Initiative. Vitamin and mineral deficiency. A global damage assessment report. 2004. https://www.unicef.org/ media/files/davos_micronutrient.pdf.

23. West K, Klemm R, Sommer A. Sound science, sound policy. J World Public Health Nutr Assoc. 2010;1(5):211-29. http://www.wphna.org/htdocs/ downloadsoctober2010/10-10\%20WN\%20Comm\%20VitA\%20west\%20 et\%20al.pdf.

24. Dubock A. Golden Rice: a long-running story at the watershed of the GM debate. 2013. p. 1-12. http://b4fa.org/wp-content/uploads/2013/10/ Viewpoints-Dubock.pdf and [printable] http://www.goldenrice.org/PDFs/ GR_A_long-running_story.pdf. Accessed 25 Sept 2017.

25. Mayo-Wilson E, Imdad A, Herzer K, Yakoob M, Bhutta Z. Vitamin A supplements for preventing mortality, illness and blindness in children aged under 5: systematic review and meta-analysis. Br Med J. 2011;343:d5094. http://www.bmj.com/content/343/bmj.d5094

26. WHO. Nutrition, micronutrient deficiencies, vitamin A deficiency. 2013. http://www.who.int/nutrition/topics/vad/en/.

27. UN. Levels and trends in child mortality: estimates developed by the United Nations inter-agency group for child mortality estimation. 2010 http://www.childmortality.org/files_v20/download/Levels\%20and\%20 Trends\%20in\%20Child\%20Mortality\%20Report\%202010.pdf.

28. UN. Levels and trends in child mortality 2015. 2015. http:// www.who.int/maternal_child_adolescent/documents/ levels_trends_child_mortality_2015/en/.

29. UNICEF. UNICEF data: monitoring the situation of children and women. Committing to child survival: a promise renewed_progress report 2014 national, regional, and global sex ratios of infant, child, and under-5 mortality and identification. 2016. http://data.unicef.org/child-mortality/ under-five.html.

30. UN. UNAIDS fact sheet 2015. 2015. http://www.unaids.org/en/resources/ campaigns/HowAIDSchangedeverything/factsheet.

31. World Health Organization. WHO fact sheet on the World Malaria Report 2014. 2014. http://www.who.int/malaria/media/ world_malaria_report_2014/en/.

32. WHO. Global Health Observatory $(\mathrm{GHO})$ data how many TB cases and deaths are there? 2014. http://www.who.int/gho/tb/epidemic/ cases deaths/en/.

33. Dubock AC. Biofortified Golden Rice as additional intervention for vitamin A deficiency, chapter 32. In: Sasaki T, editor. Achieving sustainable cultivation of rice: breeding for higher quality, vol. 1. Cambridge: Burleigh Dodds Science Publishing Limited; 2017.

34. Stevens G, Bennett J, Hennoccq Q, et al. Trends and mortality effects of vitamin A deficiency in children in 138 low-income and middle-income countries between 1991 and 2013: a pooled analysis of population-based surveys. Lancet 2015;3:e528-36. http://thelancet.com/journals/langlo/ article/PIIS2214-109X(15)00039-X/fulltext.

35. Tang G. Using plant foods rich in $\beta$-carotene to combat vitamin A deficiency. Sight Life 2013;27(1). http://www.sightandlife.org/fileadmin/ data/Magazine/2013/27_1_2013/using_plant_foods_rich_in_beta_carotene_to_combat_VAD.pdf. 
36. Bouis H, Islam Y. Biofortification, chapter 10. In: Fan S, Pandya-Lorch R, editors. Leveraging agriculture to reduce hidden hunger in reshaping agriculture for nutrition and health (an IFPRI 2020 book). 2012. https:// www.ifpri.org/publication/reshapingagriculture-nutrition-and-health.

37. Dubock A. The present status of Golden Rice. J Huazhong Agric Univ. 2014;33(6):69-84. http://www.goldenrice.org/PDFs/DubockThe_present_status_of_Golden_Rice-2014.pdf.

38. WHO. Guideline: vitamin A supplementation in infants and children 6-59 months of age. 2011. p 1-25. http://apps.who.int/iris/bitstr eam/10665/44664/1/9789241501767_eng.pdf.

39. WHO. Guideline: neonatal vitamin A supplementation. 2011. p. 1-25. http://apps.who.int/iris/bitstream/10665/44626/1/9789241501798_eng. pdf.

40. Stein A, Sachdev H, Qaim M. Potential impact and cost-effectiveness of Golden Rice. Nat Biotechnol. 2006;24(10):200-1. https://www.unihohenheim.de/uploads/media/GR-suppl.pdf.

41. Neidecker-Gonzales O, Nestle P, Bouis H. Estimating the global costs of vitamin A capsule supplementation: a review of the literature. Food Nutr Bull. 2007;28(3):307-16. doi:10.1177/156482650702800307.

42. Ye $X$, et al. Engineering the provitamin A $\beta$-carotene biosynthetic pathway into (carotenoid-free) rice endosperm. Science 2000;287(5451):3035. https://www.ncbi.nlm.nih.gov/pubmed/10634784, http://www. goldenrice.org/PDFs/Ye_et_al_Science_2000.pdf.

43. Potrykus I. From the concept of totipotency to biofortified cereals. Annu Rev Plant Biol. 2014;66(1):1-22. http://www.annualreviews.org/doi/ abs/10.1146/annurev-arplant-043014-114734.

44. Tang G, Qin J, Dolnikowski G, et al. Golden Rice is an effective source of vitamin A. Am J Clin Nutr. 2009;89:1-8. http://ajcn.nutrition.org/content/89/6/1776.short.

45. Anonymous. Tufts University statement on Golden Rice research. 2013. http://academicsreview.org/2013/09/ tufts-university-statement-on-golden-rice-research/.

46. Stokstad E. Golden Rice paper retracted after legal bid fails. Science 2015;7-9. http://news.sciencemag.org/asiapacific/2015/07/ golden-rice-paper-retracted-after-legal-bid-fails.

47. Fedoroff N. Food in a future of 10 billion. Agric Food Secur. 2015;4(11). https://agricultureandfoodsecurity.biomedcentral.com/articles/10.1186/ s40066-015-0031-7.

48. Anonymous. Welcome to the Joint FAO/IAEA mutant variety database. 2017. https://mvd.iaea.org/.

49. Paine J, Shipton C, Chaggar S, et al. Improving the nutritional value of Golden Rice through increased pro-vitamin A content. Nat Biotechnol. 2005;23(4):482-7.

50. Roberts R, Agre P, Alferof Z, et al. Support precision agriculture. Open online letter from 123 Nobel Leaureates, addressed to the Leaders of Greenpeace, the United Nations and Governments around the world. 2016. http://supportprecisionagriculture.org/.

51. European Commission. A decade of EU-funded GMO research (2001-2010). 2010. https://ec.europa.eu/research/biosociety/pdf/a_decade_of_eu-funded_gmo_research.pdf.

52. National Research Council. Transgenic plants and world agriculture. Washington, DC: The National Academies Press; 2000 doi:10.17226/9889, https://www.nap.edu/catalog/9889/ transgenic-plants-and-world-agriculture.

53. National Academies of Sciences, Engineering, and Medicine. Genetically engineered crops: experiences and prospects. Washington, DC: The National Academies Press; 2016. doi:10.17226/23395, https://nas-sites org/ge-crops/.

54. The Royal Society. Genetically modified (GM) plants: questions and answers. undated. https://royalsociety.org/topics-policy/projects/ gm-plants/.

55. Anderson K, Jackson L, Nielsen C. Genetically modified rice adoption: implications for welfare and poverty alleviation. J Econ Integr. 2005;20(4):771-88. https://siteresources.worldbank.org/INTTRADERESEARCH/Resources/544824-1154465929522/GTAPREV0405.pdf.

56. Wesseler J, Zilberman D. The economic power of the Golden Rice opposition. Environ Dev Econ. 2014;19(6):724-42. https://www. cambridge.org/core/journals/environment-and-development-economics/article/the-economic-power-of-the-golden-rice-opposition/ F31EE0E5B6044B86B5223FF20C409158.
57. Wesseler J, Kaplan S, Zilberman D. The cost of delaying approval of Golden Rice. Agricultural and Resource Economics, Giannini Foundation of Agricultural Economics, 2014;17:1-3. http://supportprecisionagriculture.org/Wesseler_Kaplan_Zilberman_2014_The_Cost_of_Delaying_Approval_of_Golden_Rice_rir.pdf.

58. Wesseler J, Zilberman D. Golden Rice: no progress to be seen. Do we still need it? Environ Dev Econ. 2016;107-9. https://www.cambridge.org/ core/services/aop-cambridgecore/content/view/1CE0005A6D5FFAB698 034B6A1E47F14C/S1355770X16000292a.pdf/golden-rice-no-progress-tobe-seen-do-we-still-need-it.pdf.

59. Greenpeace. Genetically engineered 'Golden Rice' is fools gold. Press Release. 2001. http://www.greenpeace.org/new-zealand/en/press/ genetically-engineered-golden/.

60. Dubock A. The politics of Golden Rice. GM Crop Food. 2014;5(3):210-22.

61. Tan M. (Greenpeace), 24 children used as guinea pigs in genetically engineered 'Golden Rice' trial. 2012. http://www.greenpeace.org/eastasia/ news/blog/24-children-used-as-guinea-pigs-in-geneticall/blog/41956/.

62. Tang G, Hu Y, Yin S, Wang Y, Dallal G, Grusak M, Russell R. Beta-Carotene in Golden Rice is as good as beta-carotene in oil at providing vitamin A to children (retraction of vol 96, pg 658, 2012). Am J Clin Nutr. 2015;102(3):715. doi:10.3945/ajcn.114.093229.

63. Reynolds T, Martirosyan DM. Nutrition by design: a review of biotechnology in functional food of plant origin. Funct Foods Health Dis. 2016;6(2):110-20. http://ffhdj.com/index.php/ffhd/article/view/236/465.

64. Anonymous. Philippine science academy deplores sabotage of Golden Rice trial. 2013. http://irri.org/blogs/golden-rice-blog/ philippine-science-academy-deplores-sabotage-of-golden-rice-trial.

65. Alberts B, Baulcombe D, Blobel G, et al. Standing up for GMOs. Science 2013;341(6152):1320. http://www.sciencemag.org/content/341/6152/1320.full.

66. Moore P. Confessions of a Greenpeace dropout: the making of a sensible environmentalist, chapter 16. Vancouver: Beatty Street Publishing; 2010.

67. Moore P. Greenpeace's crime against humanity. 2012. http://ecosense. me/2017/01/18/issues-2/.

68. Hope C. Campaigning against GM crops is 'morally unacceptable', says former Greenpeace chief. The Telegraph. 2015. http://www.telegraph. co.uk/news/earth/agriculture/crops/11661016/Campaigning-againstGM-crops-is-morally-unacceptable-says-former-Greenpeace-chief.html.

69. Lynas M. Lecture to Oxford farming conference. 2013. http://www.marklynas.org/2013/01/lecture-to-oxford-farming-conference-3-january-2013/.

70. International Atomic Energy Agency. quoting Naidoo K. Neuer Greenpeace-Chef will gegen Klimawandel hungerstreiken. Spiegel Online. 2009. http://www.spiegel.de/wissenschaft/natur/kumi-naidoo-neuergreenpeace-chef-will-gegen-klimawandel-hungerstreiken-a-664086. html.

71. Anonymous. World food prize 2016. 2016. https://www.worldfoodprize. org/en/laureates/2016_andrade_mwanga_low_and_bouis/.

72. UN. Cartagena protocol on biosafety to the convention on biological diversity. 2000. https://www.cbd.int/doc/legal/cartagena-protocol-en. pdf.

73. FAO of UN. Safeguarding of biodiversity must be integrated across agricultural sectors. 2016. http://www.fao.org/news/story/en/item/461656/ icode/.

74. World Bank. An overview of links between obesity and food systems implications for the agriculture gp agenda. 2017. http://www.gainhealth. org/wp-content/uploads/2017/07/Final-Overweight-Obesity-Report.pdf.

75. Alderman $\mathrm{H}$, et al. Improving nutrition through multisectoral approaches. Washington, DC: World Bank; 2013. https://openknowledge.worldbank.org/bitstream/handle/10986/16450/75102revd. pdf? sequence=5\&isAllowed=y, also https://www.popline.org/ node/566913.

76. Kyndta T, Quispea D, Zhaic H, Jarret R, et al. The genome of cultivated sweet potato contains Agrobacterium T-DNAs with expressed genes: an example of a naturally transgenic food crop. PNAS 2015;112(18):5844-49. http://www.pnas.org/content/112/18/5844.abstract.

77. UN. Report of the United Nations conference on environment and development. Annex 1. Rio declaration on environment and development. 1992. http://www.un.org/documents/ga/conf151/aconf15126-1annex1. htm.

78. UN. Convention on biological diversity. 1992. https://www.cbd.int/doc/ legal/cbd-en.pdf. 
79. Taverne D. The real GM food scandal. Prospect Mag. 2007;24-7. https:// www.prospectmagazine.co.uk/magazine/therealgmfoodscandal.

80. Adler J. The Cartagena protocol and biological diversity; biosafe or bio-sorry. School of Law, Case Western Reserve University, Scholarly Commons. 2000. http://scholarlycommons.law.case.edu/cgi/viewcontent.cgi? article $=1189 \&$ context $=$ faculty_publications.

81. Andrew P. Next generation crop precision editing can avoid marketing pitfalls of GMOs. 2015. https://www.geneticliteracyproject. org/2016/01/27/can-next-generation-crop-precision-editing-avoidmarketing-pitfalls-gmos/.

82. Raven P. Does the use of transgenic plants diminish or promote biodiversity? Nat Biotechnol. 2010;27(5):528-33. http://www.pas.va/content/ dam/accademia/pdf/sv113/sv113-raven.pdf.

83. Fedoroff N. Trump administration has opportunity to base biotech regulations on science, not fears. Genetic Literacy Project. 2017. https:// www.geneticliteracyproject.org/2017/02/13/trump-administrationopportunity-base-biotech-regulations-science-not-fears/.

84. Bruce C, Tribe D, Brooks G, Kershen D. Organic marketing report. 2014 http://hoards.com/sites/default/files/Academics-Review_Organic-Marketing-Report.pdf.

85. Miller H, Kelly J. Should trump scrap USDA's National Organic Program? 2017. https://www.geneticliteracyproject.org/2017/04/12/ trump-scrap-usdas-national-organic-program/.

86. Levitt T. Can GM-free biofortified crops succeed after Golden Rice controversy? Ecologist 2011. http://www.theecologist.org/News/news_analysis/1159571/can_gmfree_biofortified_crops_succeed_after_golden_ rice_controversy.html.

87. Ebron G. New GMO rice could fight iron, zinc deficiencies in developing world. Genetic Literacy Project. 2016. https://www.geneticliteracyproject. org/2016/02/16/new-gmo-rice-could-fight-iron-zinc-deficiencies-indeveloping-world/.
88. Trijatmiko K, Dueñas C, Tsakirpaloglou N, Torrizo L, et al. Biofortified indica rice attains iron and zinc nutrition dietary targets in the field. Scientific reports, vol. 6, article no. 19792. 2016. https://www.nature.com/articles/ srep19792.

89. Storozhenko S, De Brouwer V, Volckaert M, Navarrete O, et al. Folate fortification of rice by metabolic engineering. Nat Biotechnol. 2007;11:1277-9.

90. Blancquaert D, Van Daele J, Strobbe S, Kiekens F. Improving folate (vitamin B9) stability in biofortified rice through metabolic engineering. Nat Biotechnol. 2015;33(10):1076-8.

91. Paul J, Khanna H, Kleidon J, Hoang P, et al. Golden bananas in the field: elevated fruit pro-vitamin $\mathrm{A}$ from the expression of a single banana transgene. Plant Biotechnol J. 2017;15:520-32. doi:10.1111/pbi.12650.

92. Low J, Arimond M, Osman N, Cunguara B, Zano F, Tschirley D. A foodbased approach introducing orange-fleshed sweet potatoes increased vitamin A intake and serum retino concentrations in young children in rural mozambique. Am Soc Nutr. 2007;1320-1327. http://jn.nutrition.org/ content/137/5/1320.abstract.

93. Tang G, Gu X, Xu Q, Zhao X, et al. Green and yellow vegetables can maintain body stores of vitamin A in Chinese children. Am J Clin Nutr. 1999:70:1069-76. http://ajcn.nutrition.org/content/70/6/1069.abstract.

94. James C. Global status of commercialized biotech/GM crops: 2014. ISAAA Brief No. 49. Ithaca, NY: ISAAA; 2015. http://www.isaaa.org/resources/ publications/briefs/49/.

\section{Submit your next manuscript to BioMed Central and we will help you at every step:}

- We accept pre-submission inquiries

- Our selector tool helps you to find the most relevant journal

- We provide round the clock customer support

- Convenient online submission

- Thorough peer review

- Inclusion in PubMed and all major indexing services

- Maximum visibility for your research

Submit your manuscript at www.biomedcentral.com/submit
() Biomed Central 